\title{
Side \\ First report of lethal yellowing disease associated with subgroup 16SrIV, a phytoplasma on St. Kitts in the Lesser Antilles
}

\author{
W.A. Myrie ${ }^{1 *}$, L. Douglas ${ }^{1}$, N.A. Harrison ${ }^{2}$, W. McLaughlin ${ }^{3}$ and M. James ${ }^{4}$ \\ ${ }^{1}$ Coconut Industry Board, 18 Waterloo Road, Kingston 10, Jamaica; ${ }^{2}$ University of Florida, Fort Lauderdale, USA; ${ }^{3}$ \\ University of the West Indies, Mona Campus, Kingston 7, Jamaica; ${ }^{4}$ Ministry of Agriculture, La Guerite, Basseterre, St. Kitts \\ and Nevis
}

*E-mail: cocomax@cwjamaica.com

Received: 18 Jun 2012. Published: 01 Dec 2012.

Coconuts (Cocos nucifera) are grown as a crop and as amenity trees in many tropical countries. Caribbean countries use coconuts to enhance the aesthetics of sandy coastal beaches. Lethal yellowing (LY) as a phytoplasma disease, is the single most important plant disease affecting coconut production in some countries. This disease also affects 35 other palm species in Florida, and in various countries. LY was first observed in the Cayman Islands and Jamaica 100 years ago and became a devastating malady in the 1970s in Jamaica. Widespread mortality of coconut palm on St. Kitts, in the Leeward Islands (Lesser Antilles), became a cause for alarm during 2011. This disease had already been observed in nearby Nevis island, the other part of St. Kitts and Nevis, in 2006 (Myrie et al., 2006). Tall-type coconuts (Atlantic tall ecotype), in areas of high planting density near Conarre Bay and Dieppe Bay, have been most severely affected, although Christmas palm (Adonidia merrillii) and date palm (Phoenix dactylifera) have also died. Yellow to brown discoloration of leaves leading to defoliation and death are the most prominent symptoms observed on coconut palms. Bud rot caused by Phytophthora palmivora or LY were suspected as the most likely cause.

To determine the possible involvement of LY disease, DNA samples extracted from $50 \mathrm{~g}$ interior stem tissue and trunk tissue (Harrison et al., 2008) of 10 palms in late stages of decline were each evaluated for phytoplasma infection by a nested PCR assay employing rRNA operon primer pair P1 (Deng \& Hiruki, 1991)/P7(Smart et al., 1996) followed by LY group (16SrIV)-specific primer pair LY16Sf2/LY16-23Sr2 (Harrison et al., 2008). An rDNA product (1.64 kb) was readily amplified from five out of 10 affected palms but not from DNA of a symptomless coconut used as a negative control. AluI or HinfI endonuclease digests of nested PCR products revealed no differences in fragment profiles (Wei et al., 2007) amongst the five diseased palms, and profiles matched those generated from a known LY phytoplasma DNA included as a positive control. A phylogenetic distance tree was constructed by the neighbour-joining method and visualised by MEGA 5.0 software (Fig. 1). The branching pattern in the tree verified that the samples analysed were part of the existing lineage subgroup 16SrIV-A. Comparison of rDNA sequences $(1.64 \mathrm{~kb})$ derived from nested PCR products of LYWM1 (Lethal Yellowing Wayne Myrie 1) and LYWM2 (Lethal Yellowing Wayne Myrie 2), GenBank Accession Nos. JX070936 and JX070937 respectively, revealed that they were $100 \%$ identical to sequences of phytoplasma strains LYFL (Lethal Yellowing Florida, HQ613874) associated with coconut LY in Florida. In addition, the phytoplasmas infecting coconut on St. Kitts were identified and classified as members of subgroup 16SrIV-A upon analysis of 16S rDNA sequences using the $i$ Phyclassifier program (Zhao et al., 2009). LY continues to be a major threat to coconut and other palms. The disease is spreading and is of quarantine importance for many countries. This report will help in informing the stakeholders that are implementing phytosanitary measures in their respective countries.

\section{References}

Deng S, Hiruki C, 1991. Amplification of 16 S rRNA genes from culturable and non-culturable mollicutes. Journal of Microbiological Methods 14, 53-61. [http://dx.doi.org/10.1016/0167-7012(91)90007-D]

Harrison NA, Helmick EE, Elliott ML, 2008. Lethal yellowing-type diseases of palms associated with phytoplasmas newly identified in Florida, USA. Annals of Applied Biology 153, 85-94.

[http://dx.doi.org/10.1111/j.1744-7348.2008.00240.x ]

Myrie WA, Paulraj L, Dollet M, Wray D, Been BO, McLaughlin W, 2006. First report of lethal yellowing disease of coconut palms caused by phytoplasma on Nevis Island. Plant Disease 90, 834. [http://dx.doi.org/10.1094/PD-90-0834A]

Smart CD, Schneider B, Blomquist CL, Guerra LJ, Harrison NA, Ahrens U, Lorenz KH, Seemüller E, Kirpatrick BC, 1996. Phytoplasma-specific PCR primers based on sequences of the 16-23S rRNA spacer region. Applied and Environmental Microbiology 62, 2988-2993.

Wei W, Davis RE, Lee M, Zhao Y, 2007.Computer-simulated RFLP analysis of 16S rRNA genes: identification of ten new phytoplasma groups. International Journal of Systematic and Evolutionary Microbiology 57, 1855-1867. [http://dx.doi.org/10.1099/ijs.0.65000-0]

Zhao Y, Wei W, Lee IM, Shao J, Suo X, Davis RE, 2009. Construction of an interactive online phytoplasma classification tool, $i$ PhyClassifier, and its application in analysis of the peach X-disease phytoplasma group (16SrIII). International Journal of Systematic and Evolutionary Microbiology 59, 2582-2593. [http://dx.doi.org/10.1099/ijs.0.010249-0]

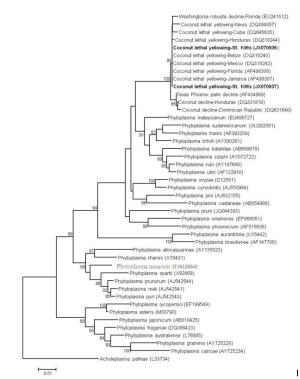

Figure 1

To cite this report: Myrie WA, Douglas L, Harrison NA, McLaughlin W, James M, 2012. First report of lethal yellowing disease associated with subgroup 16SrIV, a phytoplasma on St. Kitts in the Lesser Antilles. New Disease Reports 26, 25. [http://dx.doi.org/10.5197/j.2044-0588.2012.026.025] 